\title{
Zingiber Officinale and Curcuma Longa as Potential Functional Foods/Ingredients
}

\author{
Trinidad P. Trinidad", Rosario S. Sagum, Marco P. de Leon, Aida C. Mallillin, Melissa P. Borlagdan \\ Food and Nutrition Research Institute, Department of Science and TechnologyBicutan, Taguig City, Metro Manila, Philippines
}

\begin{abstract}
Background: Zingiberofficinale and Curcuma longa are rhizomes used as traditional medicine for gastrointestinal illnesses, motion sickness and inflammatory diseases. However, there is scarcity of data regarding its nutritional composition and functions. Objective:To characterize Zingiberofficinale and Curcuma longa as potential functional food/ ingredients Materials and Methods: Zingiberofficinale and Curcuma longa were analyzed for proximate composition, minerals, dietary fiber and phytonutrients. Mineral availability and fermentability in vitro, and antioxidant activity was also determined. Results: Curcuma longa has greater ash, fat, protein, carbohydrates and dietary fiber while Zingiberofficinale has greater moisture and $B$-carotene. Both samples were good sources of dietary fiber and when fermented in vitro, the only short chain fatty acid produced was propionate. Zingiberofficinale has significantly greater iron and calcium content.The availability of zinc (11.9 $\pm 0.4 \%)$ and calcium (56.9 $\pm 4.7 \%)$ for absorption was significantly higher in Curcuma longa but not iron (1.7 $\pm 0.1 \%$; $\mathrm{P}<0.05)$. Iron availability was significantly greater in Zingiber officinal $(21.5 \pm 3.3 \%)$. Curcuma longa has significantly greater total polyphenols, flavonoids, anthocyanidins and anti-oxidant activity. Conclusion: Zingiberoficinale and Curcoma longa are potential functional food/ingredients Food supplementation with Zingiberofficinale and Curcumin longa may be considered as a novel nutritional approach to reduce chronic diseases and mineral deficiency.
\end{abstract}

Keywords ZingiberOfficinale, Curcuma Longa, Functional Foods

\section{Introduction}

The spice ginger is the underground rhizome of the ginger plant, known botanically as Zingiberofficinale. The flesh of the ginger rhizome can be yellow, white or red in color, depending upon the variety and a taste that is aromatic, pungent and hot. The constituents of ginger are numerous and vary depending on the place of origin and whether the rhizomes are fresh or dry. The powdered rhizome of ginger has long been used in traditional medicine for alleviating the symptoms of gastrointestinal illnesses (1). The effectiveness of ginger in motion sickness (2) and cancer chemotherapy (3) has been reported. The antioxidant action of ginger has been proposed as one of the major possible mechanisms for the protective actions of the plant against toxicity (4-5).

Turmeric or Curcuma longa is an Indian spice and has been described as a treatment for inflammatory diseases andis referred by different names in different cultures (6). Turmeric has a peppery, warm and bitter flavor and a mild fragrance slightly reminiscent of orange and ginger, and while it is best known as one of the ingredients used to make curry, it also gives mustard its bright yellow color. Turmeric

* Corresponding author:

tptrinidad@yahoo.com (Trinidad P. Trinidad)

Published online at http://journal.sapub.org/fph

Copyright (C) 2012 Scientific \& Academic Publishing. All Rights Reserved has long been used as a powerful anti-inflammatory in both the Chinese and Indian systems of medicine. Turmeric has been used throughout history as a condiment, healing remedy and textile dye.The effect of curcumin on serum cholesterol and lipid peroxide levels in 10 healthy volunteers was studied (7). Daily administration of curcumin $(500 \mathrm{mg})$ for 7 days led to a significant $33 \%$ decrease in serum lipid peroxides, a $29 \%$ increase in serum HDL cholesterol, and a nearly $12 \%$ decrease in total serum cholesterol. On the other hand, there is scarcity of data regarding nutritional composition, minerals, dietary fiber and functions. Because of the many potential health benefits of Zingiberofficinale and Curcuma longa, it is of interest to study both plants grown in the Philippine soil as potential functional food/ingredient.

\section{Objectives}

The study characterized Zingiberofficinale and Curcuma longa as functional food/ingredients in terms of nutrient compostion, mineral availability, dietary fiber content and its fermentability in vitro as well as its phytonutrients and antioxidant activity.Zingiberofficinale and Curcuma longa as potential functional food/ingredients can also be made into value-added products for human consumption and may play significant roles in the prevention for risk of chronic diseases and mineral deficiency. 


\section{Methods}

\section{Test Foods, Sampling and Preparation of Samples}

The test foods used are the ordinary ginger (Zingiberofficinale) and the yellow ginger known in the Philippines as "luyangdilaw" (Curcuma longa).The samples were obtained from different markets in Metro Manila.Metro Manila was divided into four parts according to primary directions (north, south, east and west). The municipalities and cities that falls in northern direction were: Caloocan and Valenzuela; south: Muntinlupa, Las Pinas and Paranaque; west: Manila, Malabon, and Pasay; east: Quezon City, Marikina, Pasig, Taguig-Pateros, San Juan, and Makati which are the sampling sites. The purchased samples were stored in the refrigerator for pooling and sample preparation. Ordinary and yellow ginger rhizomes were washed to take away the soil and air dried.The samples were peeled and cut into small pieces. Freshly cut samples were analyzed for proximate composition, beta-carotene and total dietary fiber. The remaining samples were freeze dried and pulverized after desired dryness was achieved.

\section{Analytical Methods:}

The fresh samples were analyzed for ash, moisture, fat, protein, and carbohydrates (8), dietary fiber (9) B-carotene (10). The freeze-dried samples were analyzed for calcium, iron, and zinc (11), phytic acid (12) tannic acid (13) total polyphenols (14), flavonoids (15) and anthocyanidins (16).

Dietary fiber fermentation of test samples simulating conditions in the large intestine (colon) was determined in vitro (17). The antioxidant activity was determined using diphenyl-1-picrylhydrazyl(DPPH)(18) and ferric reducing antioxidant power (FRAP)(19) assays.

\section{Results}

Curcuma longa has greater ash, fat, protein, carbohydrates and dietary fiber than that of Zingiberofficinale. However, Zingiberofficinale has greater moisture and B-carotene(Table 1)Although both samples are good sources of dietary fiber, when fermented in vitro, the only short chain fatty acid produced was propionate (Tables 1 and 2). Both samples are also good sources of minerals, Zingiberofficinale with significantly greater iron and calcium than Curcuma longa but not for zinc (Table 3; $\mathrm{P}<0.05$ ). The availability of zinc and calcium for absorption was significantly higher in Curcuma longa but not for iron Iron availability was significantly greater in Zingiberofficinale (Table 3; $\mathrm{P}<0.05$ ). The low phytic acid and tannic acid content from both samples may not affect the availability of minerals (Table 4)

Curcuma longa has significantly greater total polyphenols, flavonoids and anthocyanidins and anti-oxidant activity than that of Zingiberofficinale. The high level of polyphenols and antioxidant activity of Curcuma longa was also observed in another study (19)

Table 1. Proximate composition, dietary fiber (g/100 g sample) and $\beta$-carotene $(\mu \mathrm{g} / 100 \mathrm{G})$ content of test foods

\begin{tabular}{|c|c|c|c|c|c|c|c|}
\hline FOOD SAMPLES & MOISTURE ASH & FAT & PROTEIN & CHO & DIETARY & FIBERß & CAROTENE \\
\hline Zingiberofficinale & 85.8 & 1.1 & 0.4 & 1.3 & 11.4 & 3.4 & 11 \\
\hline Curcuma longa & 82.7 & 1.4 & 0.6 & 1.7 & 13.6 & 6.1 & 2 \\
\hline
\end{tabular}

Table 2. Short chain fatty acid content of test foods, $\mathrm{mg} / \mathrm{g}$

\begin{tabular}{|c|c|c|c|c|}
\hline FOOD SAMPLES & TOTAL SCFA & ACETATE & PROPIONATE & BUTYRATE \\
\hline Zingiberofficinale & $37.9 \pm 12.3 \mathrm{a}$ & 0 & $37.9 \pm 12.3 \mathrm{a}$ & 0 \\
\hline Curcuma longa & $9.4 \pm 1.6 \mathrm{~b}$ & 0 & $9.4 \pm 1.6 \mathrm{~b}$ & 0 \\
\hline
\end{tabular}

ab denotes significant differences between samples at $\mathrm{P}<0.05$.

Table 3. Mineral content and mineral availability of test foods

\begin{tabular}{|c|c|c|c|c|c|c|}
\hline FOOD SAMPLES & $\begin{array}{c}\text { Total Iron } \\
\mathrm{mg} / 100 \mathrm{~g}\end{array}$ & $\begin{array}{c}\text { \% Iron } \\
\text { Availability* }\end{array}$ & $\begin{array}{c}\text { Total Zinc } \\
\mathrm{mg} / 100 \mathrm{~g}\end{array}$ & $\begin{array}{c}\text { \% Zinc } \\
\text { Availability* }\end{array}$ & $\begin{array}{c}\text { Total Calcium } \\
\mathrm{mg} / 100 \mathrm{~g}\end{array}$ & $\begin{array}{c}\text { \% Calcium } \\
\text { Availability* }\end{array}$ \\
\hline Zingiberofficinale & $3.3 \pm 0.5 \mathrm{a}$ & $21.5 \pm 3.3 \mathrm{a}$ & $22.4 \pm 0.2 \mathrm{a}$ & $4.6 \pm 0.1 \mathrm{~b}$ & $50.1 \pm 0.3 \mathrm{a}$ & $7.0 \pm 0.2 \mathrm{~b}$ \\
\hline Curcuma longa & $2.4 \pm 0.4 \mathrm{a}$ & $1.7 \pm 0.1 \mathrm{~b}$ & $22.6 \pm 0.2 \mathrm{a}$ & $11.9 \pm 0.4 \mathrm{a}$ & $8.2 \pm 0.2 \mathrm{~b}$ & $56.9 \pm 4.7 \mathrm{a}$ \\
\hline
\end{tabular}

ab denotes significant differences between samples at $\mathrm{P}<0.05$.

* estimated amount of mineral that can be potentially absorbed in the small intestine.

Table 4. Phytic and tannic acid content of test foods

\begin{tabular}{|c|c|c|}
\hline FOOD SAMPLES & PHYTIC ACID, $\mathrm{mg} / 100 \mathrm{~g}$ & TANNIC ACID, mg/100 g \\
\hline Zingiberofficinale & $11.0 \pm 0.1 \mathrm{~b}$ & $4.3 \pm 1.0 \mathrm{a}$ \\
\hline Curcuma longa & $18.4 \pm 0.2 \mathrm{a}$ & $3.0 \pm 0.6 \mathrm{a}$ \\
\hline
\end{tabular}

ab denotes significant differences between samples at $\mathrm{P}<0.05$.

Table 5. Phytonutrients and antioxidant activity of test foods

\begin{tabular}{|c|c|c|c|c|c|}
\hline FOOD SAMPLES & $\begin{array}{l}\text { TOTAL POLYPHENOLS } \\
\text { mg gallicequiv/ } 100 \mathrm{~g} \text { sample }\end{array}$ & $\begin{array}{c}\text { FLAVONOIDS } \\
\text { mg gallicequiv } / 100 \mathrm{~g} \\
\text { sample }\end{array}$ & $\begin{array}{l}\text { ANTHOCYANIDINS } \\
\text { mg catechinequiv / } 100 \\
\text { g Sample }\end{array}$ & $\begin{array}{c}\text { DPPH } \\
\% \text { inhibition }\end{array}$ & $\begin{array}{c}\text { FRAP } \\
\text { mM reduced iron }\end{array}$ \\
\hline Zingiberofficinale & $55.0 \pm 0.1 \mathrm{~b}$ & $37.0 \pm 0.1 \mathrm{~b}$ & $22.0 \pm 0.1 \mathrm{~b}$ & $32.0 \pm 0.1 \mathrm{~b}$ & $0.26 \pm 0.03 \mathrm{~b}$ \\
\hline Curcuma longa & $174 \pm 0.5 \mathrm{a}$ & $125.0 \pm 0.2 \mathrm{a}$ & $129.0 \pm 0.1 \mathrm{a}$ & $54.0 \pm 0.1 \mathrm{a}$ & $0.63 \pm 0.04 \mathrm{a}$ \\
\hline
\end{tabular}

$\mathrm{ab}$ denotes significant differences between samples at $\mathrm{P}<0.05$. 


\section{Discussion}

The fermentable dietary fiber from Zingiberofficinale and Curcuma longa was shown to produce only the short chain fatty acid, propionate which was significant for both samples indicating protective effect for cholesterol-lowering. Propionate release in the colon after dietary fiber fermentation is readily taken up by the liver. Its action is to inhibit the limiting enzyme HMG Co-enzyme reductase for cholesterol synthesis(20). The cholesterol lowering effect of Curcuma longa was studied in humans in another study(7).

There is a scarcity on the data on mineral composition and the availability of minerals for potential absorption in the small intestine from Zingiberofficinale and Curcuma longa. The study showed that both samples are good sources of iron, zinc and calcium. However, differences in their mineral availability for absorption were observed and may be due to its mineral content and/or mineral-mineral interaction (21-23). For example, when iron availability is high, both zinc and calcium availability is low, and when iron availability is low, zinc and calcium availability is high.The differences in mineral availability from both samples may not be due to phytic and tannic acid due to its low content (Table 4).

The non-flavonoid polyphenol curcumin is the major phenolic compound found in Curcuma longa which has long been used as a traditional Indian medicine(24). Many studies on curcumin have shown anti-cancer agent, anti-inflamatory actions and significant anti-microbial ability(6, 25-27).In a recent study conducted on Curcumin longa, it was observed that it contained high levels of polyphenols and strong antioxidant activity(19).This was similar to the results obtained from thisstudy.According to the present study, aside from the non-flavonoid polyphenol curcumin found in other studies, flavonoid and anthocyanidin are also present in Curcumin longa.

On the other hand, Zingiberofficinale although found to contain lesser amounts of total polyphenols, flavonoids and anthocyanidins than that of Curcuma longa may have other phenolic constituent that was not determined in this study. In some studies it was shown that the phenolic constituent found in Zingiberofficinale, 6-gingerol was found to suppress carcinogenesis in the skin gastrointestinal tract, colon and breast(28-31). Also, ginger extracts have been tested for both anti-tumor promotion and apoptotic potential in several in vitro cell lines, including leukemia, gastric, prostate, ovarian, and lung carcinoma (31-35).

\section{Conclusions}

Zingiberoficinale and Curcoma longa are potential functional food/ingredients not only because of being known as good sources of antioxidants but also as a good source of dietary fiber and minerals.Food supplementation with both Zingiberofficinale and Curcumin longa may be considered as a novel nutritional approach to reduce chronic diseases as well as mineral deficiency.

\section{ACKNOWLEDGEMENTS}

The authors are grateful to Ms. Teresa S. Mendoza, Project Coordinator of "Intensifying R\&D and S\&T Programs on Functional/Nutritional Food/Products for the Food Industry" and "Sustaining Food Product Development on Functional Foods" where this study is a part of the programs, and to the Philippine Council for Industry, Energy and Emerging Technology Research and Development for funding the study.

\section{REFERENCES}

[1] Afzal M, Al-Hadidi D, Menon M, Pesek J, DhamiMSI.Ginger:Amethnomedical, chemical and pharmacological review, drug metabolism and drug interaction. 2001; 18:159-190.

[2] Stewart JJ, Wood MJ, Wood CD, Eims ME. Effects of ginger on motion sickness susceptibility and gastric function. Pharmacology 1991; 42:111-120.

[3] Sharma Ra, McLelland HR, Hill KA, Ireson CR, Euden SA, Manson MM,Pirmohamed M, Marnett LJ, Gesher AJ, Steward WP. Pharmacodynamic and pharmokinetic study of oral Curcumin extract in patients with colorectal cancer.Clin Can Res 2001; 7:1894-1900.

[4] Jagetial GC, Baliga MS, Venkotesh P, Ulloor JN.Influence of ginger rhizome (Zingiberofficinale) on survival, glutathione and lipid peroxidation in mice after whole body exposure to gamma radiation.Radiation Research 2003; 160:584-592.

[5] Haksar A, Sharma A, Chaula R, Kumar R, Arora R, Singh S, Prasad J, Gupta M, Tripathi, RP, Arora MP, Islam F, Sharma RK. Zingiberofficinale exhibits behavioral radioprotection against radiation induced CTA in a gender specific manner.Pharmacology Biochemistry and Behavior 2006; 84:179-188.

[6] Aggarwal BB, Van Kuiken ME, Iyer LH, Harikumar KB, Sung B.Molecular targets of nutraceuticals derived from dietary spices: potential role in suppression of inflammation and tumorgenises.ExptBiol and Med 2009; 234:825-849.

[7] Kuttan G, Kumar KB, Guruvayoorappan C, Kuttan R. Antitumor, anti-invarion and antimetastatic effects of curcumin.AdvExp med Biol 2007; 595:173-184.

[8] Association of Official Analytical Chemist (2000). Official Methods of Analysis, 17th ed. 991.43 Supplement.

[9] Association of Official Analytical Chemist (1995). Official Methods of Analysis, 941.15 Carotene in fresh plant material and silages:spectrophotometric method.

[10] Association of Official Analytical Chemist (2000). Official Methods of Analysis, 17th ed. 985.35.

[11] Association of Official Analytical Chemist (1986).Phytate in foods: anion exchange method. J Assoc Off Anal Chem, 69, p. 2

[12] Earp CF, Ring SH, Rooney LW. Evaluation of several methods to determine tannins in sorghum with varying kernel 
characteristics. Cereal Chem 1981; 58:134-138.

[13] Velioglu KT. Total Phenolic of Some Food Plants. Shanghai, Science and technology Press 1998; 28:25-30.

[14] Zhishenh T.,Zhong L. Total Flavanoids of Chinese Herbs. Journal of Food Chemistry, 1999; 88: 411-417.

[15] Sun Y.Y., Kirvanta J., Analysis of Anthocyanidin and Variation of Phenolic Substances in Onion, ActaPharmaceut, 1998; 97: 67-72.

[16] McBurney and Thompson LU. In vitro fermentabilities of purified fiber supplements. J Food Sci 1987; 54:347-350.

[17] Brand-Williams W, Cuvelier M.E. and Berst C. DPPH Antioxidant Analysis: Use of stable Free Radical in Evaluation of Antioxidant Activity. LebensmWiss. Technol Journal of Food Nutrition, 1995; 28-30.

[18] Benzie F.I, Strain JJ, Ferric Reducing Antioxidant Power, Journal of Food Chemistry, 1996; 299:15-27

[19] Kang C, Kim E. Synergistic effect of curcumin and insulin on muscle cell glucose metabolism. Food ChemToxicol 2010; 48(8-9):2366-2373.

[20] Chen WJL, Anderson JW, Jenkins DJA.Propionate may mediate the hypocholesterolemic effects of certain soluble plant fibers in cholesterol-fed rats.ProcSocExpBiol Med 1984; $175: 215-218$

[21] Cook JD, Dassenko SA, Whittaker P. Calciumsupplementation effect on iron absorption.Am J ClinNutr 1991; 53:106-111.

[22] Davidsson L, Kastenmayer P, Hurrell RF.Sodium iron EDTA as a food fortificant:the effect on the absorption and retention of zinc and calcium in women. Am J ClinNutr 1994; 60:231-237

[23] Davidsson L, Almgren A, Sandstrom B.Zinc absorption in adult humans:the effect of iron fortification. Br J Nutr 1995; 74:417-425

[24] SelvamR,Subramanian L, Gayathri R, Angayarkanni N. The antioxidant activity of turmeric (Curcuma longa). J Ethnopharmacol 1995; 47:59-67.
[25] Rao TS, Basu N, Siddigui HH. Anti-inflammatory activity of curcumin analogues. Indian J Med Res 1982; 75:574-578.

[26] Wesler S, MuenznerP, Peyer TF, Naumann M. The anti-inflammatory compound curcumin inhibits Neisseria gonorrhoeae-induced NF-kappa B signaling, release of pro-inflammatory cytokines/chemokines and attenuates adhesion in late infection.BiolChem 2005; 386:481-490.

[27] Chen HW, Lee JY, Huang JY, Wang CC, Chen WJ.Curcumin inhibits lung cancer cell invasion and metatasis through tumor suppressor HLJ1. Cancer Res 2008; 68:7428-7438.

[28] Murakami A, Tanaka T, Lee JY.Zerumbone, a sequiterpene in subtropical ginger, suppresses skin tuor initiation and promotion stages in ICR mice. Int J Can 2004; 110:481-490.

[29] Bode A. Ginger is an effective inhibitor of HCT116 human colorectal carcinoma in vivo. Frontiers in Cancer Prevention Research Conference, Phoeniz (AZ):2003.

[30] Nagfasawa H, Watanabe K, Inatomi H. Effects of bitter melon (Mamordicacharantia 1.) or ginger rhizome (Zingiberofficinale rocs) on spontaneous mammary tumorgenesis in SHN mice. Am J Clin Med 2002; 30:195-205.

[31] Lee E, Surh YJ. Induction of apoptosis in HL-60 cells by pungent vanilloids, [6]-gingerol and [6]-paradol. Cancer Lett $1998 ; 134: 163-168$

[32] shiguro K, Ando T, Maeda O. Ginger ingredients reduce viability of gaster cancer cells via distinct mechanisms.BiochemBiophys Res Commun 2007;362:218-223.

[33] Nonn L, Duong D, Peehl DM.Chemopreventive anti-inflammatory activities of curcumin and other phytochemicals mediated by MAP kinase phosphatase- 5 in prostate cells. Carcinogenesis 2007; 28:1188-1196.

[34] Rhode J, Zick SM, Fogoros S. Ginger induces apoptosis anthophagocytosis and growth inhibition in ovarian cancer cells.BMC Complementary Medicine. In press 2007.

[35] Wang G, Li X, Huang F Antitumor effect of ß-elemene in non-small-cell lung cancer cells ismediated via induction of cell cycle arrest and apoptotic cell death.Cell Mol Life Sci 2005;62:881-893 